いる。

安全装置は棒の形をしており、プレス 上半部が下降中に障害物に棒が触れると 電気回路が切れて、プレスが止る様にな っている。

圧力スイッチもバッグと接続している 導管につけてあり、バッグ中に圧力がま だある中にプレスが開かれることのない 様にしてある。

このプレスは英国では自動成型タイヤ 加硫機 (Autoform Tyre Vulcanizer) と呼ばれており、現在は $12.00 \times 20$ 迄の タイヤの出来る $40 \mathrm{in} ., 45 \mathrm{in}$ 及び $55 \mathrm{in} の$ ものが製作されている。

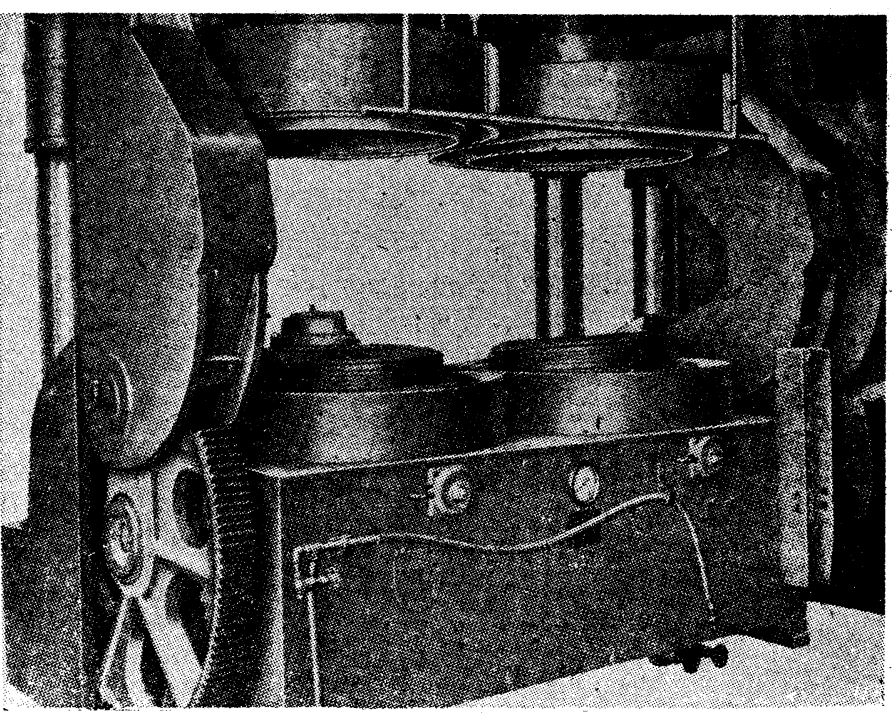

プレスが開かれ、タイヤが上型から突き 落されて、下型の上に載つているところ

\title{
ダイヤルゲージ・マイクロメーター によるゴムの厚さの測定
}

\begin{abstract}
緒言
ゴム工業の多くの部門において、ゴム試料の厚さを測 定することは非常に重要なことであり、又管理上必要な 事である。例えばカレンダー操作においては厚さを嚴密 に管理する必要が要求される。又試験室においては各試 験の一段階毎に試料の厚さを確実に測定しなければなら ない。

金属、石、或は木の如き“硬い”物質に比してゴムは 軟かいため測定中に変形しやすい。従ってその厚さを正 確に決定するのは容易なことではない。シートに変形を 与えないで厚さを精密に測定する測定法は種々あるが、 (例えば光学的装置) 通常そのような装置は高価で且つ その操作に多大の時間を必要とし不便である。普通に使 用されている厚さ測定器の主なものはノギス、マイクロ

\footnotetext{
*, 東京工業大学
}

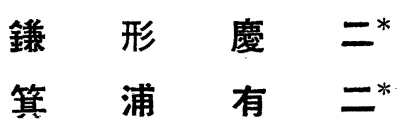

メーターなどであるが、これらは測定圧が一定でないと か、目盛みの読取りが容易でないとか、又連続測定が出 来ないとかいう久陥がある。ゴムの厚さの測定にも、こ れら“硬い"物質に使用されている器具が用いられるが その場合出来るだけ僅かの変形で測定值が与えられるよ うに改作される必要がある。

ゴム工業に採用されている（或は改作されて）測定器 具は、ダイヤルゲージ・マイクロメーターである。ここ では R.F.Blackwell1) に従ってダイヤルゲージ・マイ クロメーターによるゴム試料の厚さ測定に関する注意に ついて述べることにする。この器具は比較的安価で且つ 目盛がよみ易く、多くの目的に充分な精度を持ってい る。又ゴム試料に及ぼす圧力は内部のバネ或は死荷重に よって固定することができる。㫿試料に必ずいいらが の圧力を加えなければならないということが点であ る。云いかえればゴムを或る程度変形させなければなら 
ないということである。軟いゴムの時は変形は大きくな るし、又硬いゴムの時は変形は小さい。それ故ダィヤル ゲーシ・・イクロメーターでは変形を受けない真のゴム の厚さを測ることは出来ない。

厚さの読みはゴムに及ほすす圧力の大いさによる。従っ て、ある器具で測った厚さが他の器具で測った厚さと一 致する為には測定条件を指定する必要がある。それ故ゴ ムの厚さを質問するとき、"このゴムシートはどの位の 原さがあるか?" とたずねるのでなく"指定された条件 で測った時どの位の厚さを示すがというふうにたずね るべきである。

\section{指定された条件}

イギリスの多くの実験室では、英国規格協会の勧告に より B.S (British Standard) 903 (1950)2)に従って いる。Tensile ring や Dumb-bell の厚さの測定につ いて B.S.903 は"マイクロメーターのゲージの読みが $0.05 \mathrm{~mm}$ 或いはこれ以下のときは、その測定子のゴムに 与える圧力は $3 \mathrm{lb} / \mathrm{in}^{2}\left(200 \mathrm{~g} / \mathrm{cm}^{2}\right)$ にする゙ と規定して いる。

又我が国では JIS K6301 (1950) により、“測厚器は $1 / 100 \mathrm{~mm}$ の目盛を有し、かつ加告面が平滑であって直 径 $5 \mathrm{~mm}$ の円型のものでなければならない。測厚器の加 质荷重は $80 \mathrm{~g}$ を標準とし、測定範囲内において $15 \%$ 以 上変化しないものでなければならない”。と指定してい る。

今日ゴム工業に使用されているダイヤルゲージのどの 位の数が、実際この勧告に従っているのであろうか? 更 に従っているにしてもどの位のゲージの精度が期待でき るか? 又他のどんな要因が測定に関与するか? 考えてみ よう。

British Rubber Producers Research Association が 最近行ったイギリスにおける試験法調查では、厚さ測定 器の測定子にかかる圧力は50へ $400 \mathrm{~g} / \mathrm{cm}^{2}\left(3 / 4 \backsim 61 \mathrm{~b} / \mathrm{in}^{2}\right)$ の広い範囲のものが用いられていることを示している。

これは嚴密に代表的な例でないかも知れないが、少く ともすへてのゲージが勧告に従っているわけではないこ とを示している。Newton3) は1945年の調査で、ある実 験室では $3,500 \mathrm{~g} / \mathrm{cm}^{2}$ (約 $50 \mathrm{lb} / \mathrm{in}^{2}$ ) の圧力のものを 使用していると述べている。

\section{ダイヤルゲージの精度}

ダイヤルゲージの精度は B.S. 907(1954)4) では次の
如く指定している。"ゲージは $1 / 1,000$ まて較正され、 最大許容誤差は $2 \mathrm{~mm}$ 以上の読みに対しては0.025 mm である。それは $1 / 10 \mathrm{in}(2.5 \mathrm{~mm})$ の厚さの試料に対 しては土1\%に等しい”。

又ダイヤルゲージは直接測定用としてでなくサイズ 既知のスタンダード5) と共に “comparators”として 試験せんとする寸法を比較するために使用してもよい 事をB. S. 907において述べている。この目的に使用さ れるときは許容誤差は $0.005 \mathrm{~mm}$ である。それは $1 / 10$ in のシートにおいて $0.2 \%$ に相当する。スタンダー ドとしてはゲージブロックが用いられる。これらのブ ロックは使用に当って注意を要し、それはゲージの較 正を照合し、補正表や補正曲線をつくり得る人のみが 使用することが望ましい。

\section{厚さの測定に関係する他の要因}

ゲージのゴムに及ぼす圧力の他に考慮を要する要因 が二つある。それは測定子と測定盤の非平行性である。 この平行性の非常に欠けているゲージが時々見受けら れる。この場合測定子の底面は一点で接触している。

一様に接触させて使用する為には特別の注意が必要で ある。正確な読みを得るためには、接触面はプランヂ ャーに対し直角で、測定盤に平行であることが必要で ある6)。

これらの三つの要因、即ち圧力、測定子の大きさ、 平行性の欠如の変動による厚さ測定時のバラッキにつ いての実験報告の概要を次に述べる。

\section{実 験}

ダイヤルゲージ厚さ試験器はダイヤルが $1 / 100 \mathrm{~mm}$ まで較正され、その精度は使用せる全範囲にわたって 補正され B.S. 907 (1954) の指定に従っているものを 用いた。硬度が広範囲にわたるように四種類のゴム試 料を選び、各々の試料の嬮さのよみが同一位置でなさ れるよう注意した。厚さは一定範囲内の圧力において 種々の大きさの測定子により測定された。低い圧力は 平衡錘のみで行い、又大きな圧力はスピンドルの上に 死荷重をかけて行つた。荷重は使用せる測定子に対し $50 ， 100 ， 200$ 及び $400 \mathrm{~g} / \mathrm{cm}^{2}$ の圧力になるよう計算さ れた。真の圧力は以下に記した方法で測定した。

各々の測定子の非平行性はスピンドルに接触している 測定盤を単に回転するだけで変化した。時には必要に応 じ測定子にパッキングを入れたり、ヌ他のダイヤルゲー 


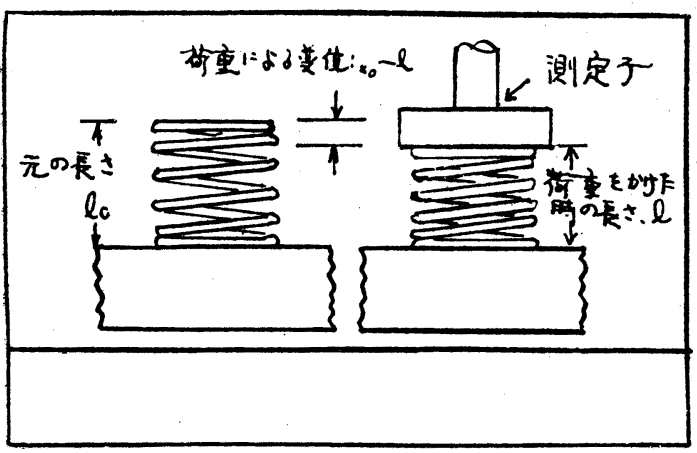

第 1 図荷重の測定

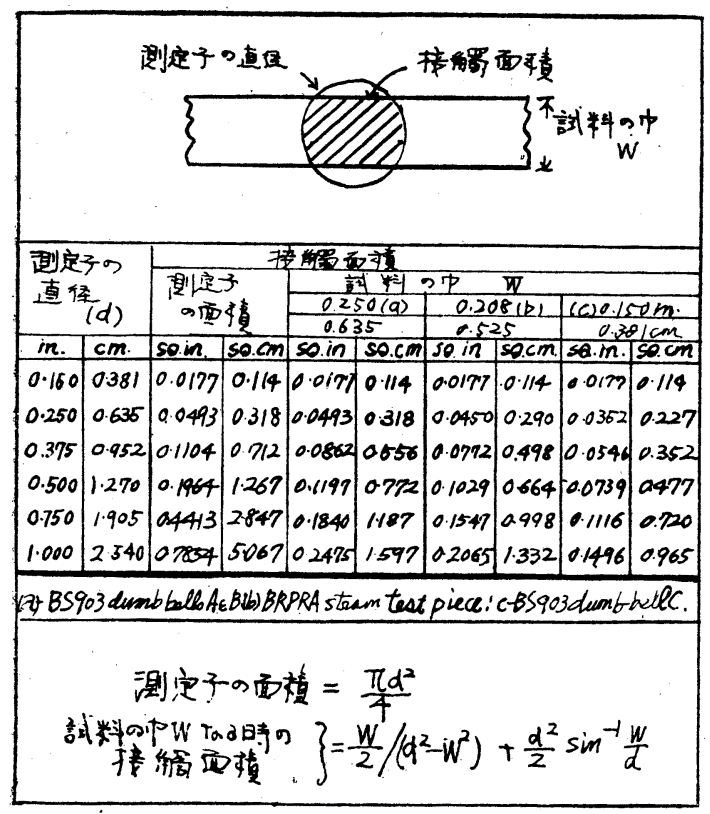

第 2 四 ゴムと測定子の接触面積

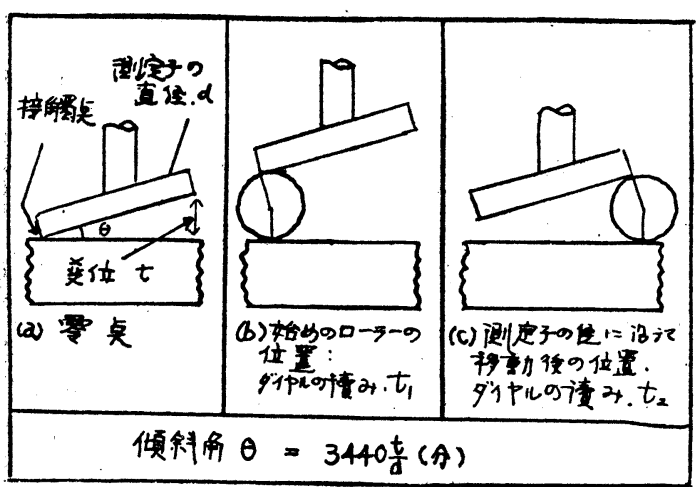

第 3 図 傾斜角の測定

シと交換したりした。荷重をかけない場合の厚さの測定 には各シートについて半球の測定子がシートと接触する 点の読みを用いた。この接触は拡大鏡を使用して観察し たが、その精度はあまりょくない。又装置の軽い振動の 為に、すべての読みに対しダイヤルゲージの摩擦による 影響を知ることが必要である。

\section{圧力の 測 定}

ゴム試験片にかかるゲージの荷重（gr）を測定のため に、80g (約 3 オンス) 荷重以上の範囲において、荷重 による変形既知の小スプリング（6回巻 22s.w.g.スチ ールスプリング、5/16in. i.d., 3/8in 長)を用いた。

(第1 図)

$\mathrm{cm}^{2}$ で表わした測定子の面積に分配された荷重は（g/ $\mathrm{cm}^{2}$ ) で圧力を示す。大切なことは圧力はゴムと測定子 の真の接鳋面積について測定されなければならないとい うことである。しかしそうでない場合もある。例えばダ ムベル型試験片の厚さを測定するに用いられる直径 1 in の測定子はゴムと接触するのは 1 部分であり、その結果 真の接触面積は測定子の面積より小さくなる。もし測定 子全体がゴムと接触しているとき $3 \mathrm{lb} / \mathrm{in}^{2}$ の圧力を及涩 すべきゲージをB.S.903によるB型ダムべルの厚さ測定 に使用するとそのときは $9.51 \mathrm{l} / \mathrm{in}^{2}$ の圧力を及ほすこと になるであろう。又C型のダンベル型試験片のときは $15.75 \mathrm{lb} / \mathrm{in}^{2}$ の圧力がかかることになるであろう、第 2 四は大きさの異なる測定子を巾の異なる試験片の接触面 積との関係を示す。

\section{傾 斜の 測 定}

測定子と測定盤の非平行度即ち傾斜はローラーゲージ を使用すれば充分な精度で測定できる。ローラーゲージ とは半径一定の円型の断面をもつ Steel のシリンダーで ある。この目的に使用するゲージは大きい程よいが $5 \backsim$ $8 \mathrm{~mm}(3 / 16 \backsim 5 / 16 \mathrm{in})$ の直径をるつローラーが適当であ ろう。この方法の原理を第 3 図に示す。

測定子と測定盤の接触点（第3a図）は器具の試験によ って知る事が出来る。ローラーをこの点で測定子の底面 がローラーの曲面に切線を為すように挿入される。（第 $3 b$ 図) この時のダイヤルゲージの読み $\left(\mathrm{t}_{1}\right)$ を記録する。 次にローラーを測定子と測定盤の間隔が最も大きくなる 位置まで直径に沿うて移動させる。ここで又読み $\left(\mathrm{t}_{\mathbf{2}}\right)$ を記録する。

正しい位置を得るために拡大鏡を使えばよい。変位 $\mathrm{t}$ は、この読みの差に等しい。傾刹角 $\theta$ は 


$$
\sin \theta=\mathrm{t} / \mathrm{d}
$$

によって与えられる。 $\mathrm{d}$ は測定子の直径である。この測 定で角度が小さい場合は角度の正昡は $1 / 1,000$ 以上の精 度で角度に比例する。( $\theta=100^{\prime}$ なるとき $\sin \theta=0.0291$ である)。故に $\theta$ は次の関係式より計算される。

$$
\theta=3.440 \mathrm{t} / \mathrm{d} \text { (分) }
$$

ここで注意しなければならないことは、ローラーゲージ の直径は傾斜の計算に入らないということである。

一例として、3/8in の測定子が8.000 及び $7.950 \mathrm{~mm}$ の 読みを与えたとすると、変位 $\mathrm{t}$ は $0.050 \mathrm{~mm}$ であ。この 測定子の真の直径が $9.540 \mathrm{~mm}$ であると傾斜角 $\theta$ は次の 如く計算される。

$$
\theta=3.440 \times 0.050 / 9.540=18 \text { (分) }
$$

この方法の精度は 5 〜10\%である。この程度の值なら ば精巧な装置を使用しなくとも出来る。

第 4 困に $200 \mathrm{~g} / \mathrm{cm}^{2}$ の圧力測定子における傾斜角と厚 さの関係を示す。

この困の縦軸は荷重をかけない場合の厚さよりの減少 (百分率)を示す。この図より明らかなるように厚い試 料ほど傾斜角の影響が大きく、又硬質ゴムより軟質ゴム のときの方が影響される。軟質ゴムでは 1 度の傾科に対 し、みかけの厚さは $4 \%$ 程減少するが、硬質ゴムでも 3

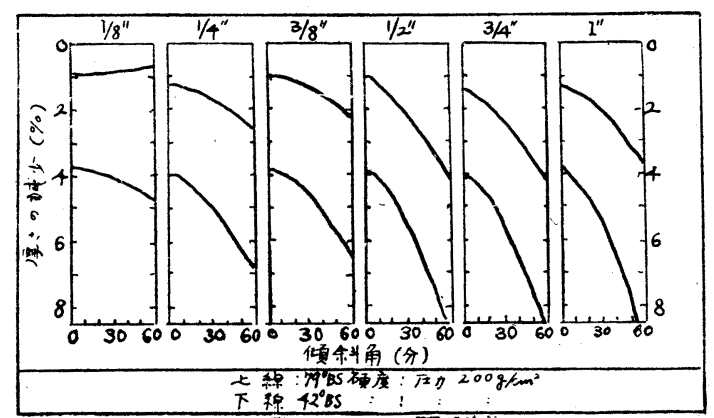

第 4 図 厚さと傾斜角

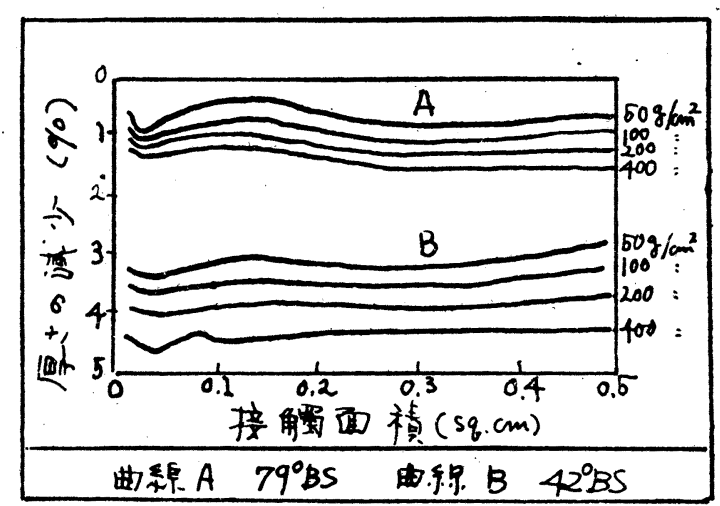

第 5 図 厚さと接鰠面積
\%近くの減少する。実際傾科はある場合には、圧力の変 動よりもかなり大きい影響を示す。この理由は測定子と ゴムの接鳋面積が傾斜が増加するにつれて減少し、又圧 力が大きくなり、その結果厚さのよみは小さくなる。普 通使用されている厚さ試験器では傾斜は大きい場合でも 52, 57 及び64分、小さい場合には 0,1 及び 2 分の角度で ある。これらの傾科は時として測定盤の回転によって変 化するが、そうでないこともある。これらの結果から見 て傾斜は約 5 分が許容しうる最大値であると考えられ る。

\section{圧力と接觸面積}

第 5 図は力による接鰠面積と厚さの関係を示したもの である。

4 種の圧力のどの場合においても、厚さ減少のカーブ はフラットである。接鳋面積は圧力が一定に保たれるな らば影響は少ないと結論してもよい。しかし小さな測定 子が使用されるときは一定圧力を与えるに要する実荷重 が小さいので、或る場合には、特に硬いゴムの場合には 多くゴムと測定盤の間の air trapping によるシートの 軽いそりを抑えるために荷重が不充分なことがある。シ 一トを静かにおさえればその影響は可なり少なくなる。 このような影響はダムベル型に切つた細長片のゴムに表 われるかどうかわからない。圧力を增加すれば特に軟質 ゴムでは期待される見かけの厚さに、多少の影響が現わ れる。けれどもこの影響は傾斜の增加によるもの程大き くはない。

\section{要 約}

ゴム試験片の見かけの厚さは、測定条件により大いに 影響される。ダイヤルゲージ・トイクロメーターで得ら れる厚さのよみを支配する主な要因は（ゲージ自身の精 度以外の）測定子と测定盤の非平行性と、測定子のゴム に及ぼす圧力であると考えられる。この二つの量を測定 する方法を記述し、ヌこれに関する実験例を簡単に説明 した。

\section{女 献}

1) R. F. Blackwell: India Rubber J.,127, No.8. 311 (1954)

2) B. S.903: (1950) "Methods of Testing Vulcanized Rubber," Part 15, Clause 15.511, P. 92

3) R.G. Newton: J.Rubber Research., 14, 120 (1945)

4) B.S. 907 (1954) "Dial gauges for Linear Measurement" Table 1-3, P.11, 12

5) Ibid. Note 3, P. 11

6) B. S. 907 (1954) Appendix C.P 19 